2013s-46

\title{
Female Labour Force Participation in MENA's Manufacturing Sector: The Implications of Firm-related and National Factors
}

\author{
Ali Fakih, Pascal L. Ghazalian
}

Série Scientifique
Scientific Series

Montréal

Décembre 2013

(C) 2013 Ali Fakih, Pascal L. Ghazalian. Tous droits réservés. All rights reserved. Reproduction partielle permise avec citation du document source, incluant la notice (C).

Short sections may be quoted without explicit permission, if full credit, including (C) notice, is given to the source.
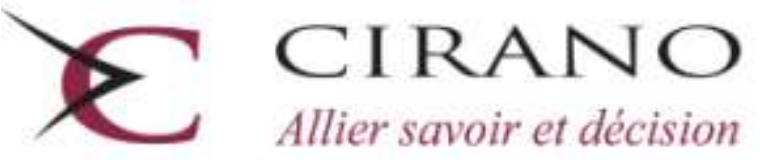

Centre intenutiversitaire de recherche en analyse des organisations 


\section{CIRANO}

Le CIRANO est un organisme sans but lucratif constitué en vertu de la Loi des compagnies du Québec. Le financement de son infrastructure et de ses activités de recherche provient des cotisations de ses organisations-membres, d'une subvention d'infrastructure du Ministère de l'Enseignement supérieur, de la Recherche, de la Science et de la Technologie, de même que des subventions et mandats obtenus par ses équipes de recherche.

CIRANO is a private non-profit organization incorporated under the Québec Companies Act. Its infrastructure and research activities are funded through fees paid by member organizations, an infrastructure grant from the Ministère de l'Enseignement supérieur, de la Recherche, de la Science et de la Technologie, and grants and research mandates obtained by its research teams.

\section{Les partenaires du CIRANO}

\section{Partenaire majeur}

Ministère de l'Enseignement supérieur, de la Recherche, de la Science et de la Technologie

\section{Partenaires corporatifs}

Autorité des marchés financiers

Banque de développement du Canada

Banque du Canada

Banque Laurentienne du Canada

Banque Nationale du Canada

Banque Scotia

Bell Canada

BMO Groupe financier

Caisse de dépôt et placement du Québec

Fédération des caisses Desjardins du Québec

Financière Sun Life, Québec

Gaz Métro

Hydro-Québec

Industrie Canada

Investissements PSP

Ministère des Finances et de l'Économie

Power Corporation du Canada

Rio Tinto Alcan

State Street Global Advisors

Transat A.T.

Ville de Montréal

\section{Partenaires universitaires}

École Polytechnique de Montréal

École de technologie supérieure (ÉTS)

HEC Montréal

Institut national de la recherche scientifique (INRS)

McGill University

Université Concordia

Université de Montréal

Université de Sherbrooke

Université du Québec

Université du Québec à Montréal

Université Laval

Le CIRANO collabore avec de nombreux centres et chaires de recherche universitaires dont on peut consulter la liste sur son site web.

Les cahiers de la série scientifique (CS) visent à rendre accessibles des résultats de recherche effectuée au CIRANO afin de susciter échanges et commentaires. Ces cahiers sont écrits dans le style des publications scientifiques. Les idées et les opinions émises sont sous l'unique responsabilité des auteurs et ne représentent pas nécessairement les positions du CIRANO ou de ses partenaires.

This paper presents research carried out at CIRANO and aims at encouraging discussion and comment. The observations and viewpoints expressed are the sole responsibility of the authors. They do not necessarily represent positions of CIRANO or its partners. 


\title{
Female Labour Force Participation in MENA's Manufacturing Sector: The Implications of Firm-related and National Factors
}

\author{
Ali Fakih ${ }^{*}$ Pascal L. Ghazalian ${ }^{\dagger}$
}

\begin{abstract}
Résumé/abstract
This paper examines the implications of firm-related and national factors for Female Labour Force Participation (FLFP) rates in manufacturing firms located in the Middle East and North Africa (MENA) region. The empirical investigation uses data derived from the World Bank's Enterprise Surveys database and applies fractional logit models to carry out the estimations. The results reveal positive implications of many firm-related factors, mainly private foreign ownership and exporting activities, for FLFP rates. National factors, such as economic development and gender equality, are also found to promote FLFP rates. These effects are generally found to be more important for women's overall labour participation rates than for women's non-production labour participation rates.
\end{abstract}

Mots clés : Female labour force participation, fractional logit model, manufacturing firms, MENA region

Codes JEL : J16, J21, J23, J82

\footnotetext{
* Assistant Professor, Department of Economics, School of Business, Lebanese American University, Beirut, Lebanon, P.O.Box: 13-5053, E-mail: afakih@lau.edu.lb

${ }^{\dagger}$ Corresponding author. Associate Professor, Department of Economics, University of Lethbridge, Lethbridge, Alberta, Canada, T1K 3M4, E-mail: pascal.ghazalian@uleth.ca
} 


\section{Introduction}

Increasing the rates of Female Labour Force Participation (FLFP) remains an essential item on the policy agenda of the Middle East and North Africa (MENA) region. Despite that MENA countries have realized substantial achievements in several major areas of women's well-being through the past few decades ${ }^{1}$, MENA's record in terms of FLFP is still lagging behind many geo-economic regions and remains one of the lowest in the world (Morrison et al., 2008; The World Bank, 2011; International Labour Organization, 2012). Table 1 presents some comparative statistics that illustrate labour force characteristics of the MENA region, sub-grouped into the Middle East (ME) and North Africa (NA), and those of other geo-economic regions through recent years. It shows that the MENA region has generally realized higher annual employment growth rates compared to other geo-economic regions. However, it also has the highest unemployment rates for youth and women, and the lowest employment-to-population ratio for women. The World Bank (2011) reports that around 50\% of women in developing countries are either employed or actively looking for jobs compared to $25.2 \%$ in the MENA region. In addition, it notes that the low FLFP rates mainly reflect the social and cultural norms that restrict women from actively participating in the labour market outside their home. ${ }^{2}$ Rauch and Kostyshak (2009) indicate that MENA's Arab countries have laws that prohibit labour discrimination in the workplace. They argue that the lower levels of FLFP have to stem from de facto discrimination rather than from de jure discrimination. Klasen and Lamanna (2009) note that women in the MENA region face structural barriers in employment, in addition to social and cultural impediments limiting their participation in the labour market.

\footnotetext{
${ }^{1}$ Most countries in the MENA region have dedicated significant resources to women's education over the past few decades. For example, since the 1990s, MENA countries have enjoyed substantial growth in female enrolment in primary and secondary education and have benefited from some progress in female enrolment in tertiary education (Morrison et al., 2008).

${ }^{2}$ See also Chamlou et al. (2011) who find that traditional social norms reduce the participation of women in the labour market in Jordan.
} 
It is important to understand the reasons behind the prevailing low FLFP rates in MENA countries and the various factors that could contribute in raising these rates. This is because gender inequality in the labour market restrains economic growth and would result in under-exploited production resources (Klasen and Lamanna, 2009; Cuberes and Teignier-Baqué, 2011; International Labour Organization, 2012). Hence, examining the factors that determine the FLFP rates would provide information and directions to policy-makers to develop relevant strategies aiming to increase women's economic opportunities.

There is a wide strand of empirical literature that examines the determining factors of FLFP (e.g., Mincer, 1962; Gronau, 1973; Heckman, 1974; Killingworth and Heckman, 1986; PrietoRodríguez and Rodríguez-Guitiérrez, 2003; Greenwood et al., 2005; Kahora, 2010; Karaoglan and Okten, 2012; Klasen and Pieters, 2012). This strand of literature has primarily focused on the supplyside factors, mainly demographic and household-related characteristics using household survey data. However, firm-related factors which influence the participation rates of women in the labour force have received less attention. The corresponding literature commonly hypothesizes that low FLFP rates could be explained by demand-side factors where firms do not offer enough jobs that attract women to participate in the labour market. Thus, low FLFP rates could be also associated with employers' preferences and characteristics (Pissarides et al., 2005). Lee et al. (2008) find that the low rates of FLFP among married women are driven by demand-side factors in South Korea. Buchanan et al. (2010) underline the importance of demand-side factors that affect the FLFP rates, particularly the demand for skilled workers. Abe (2011) concludes that a combination of supply-side and demand-side factors explains the FLFP rates in Japan.

A number of studies examine the implications of economic growth for women's participation in the labour force (e.g., Goldin, 1995; Mammen and Paxson, 2000; Tansel, 2001; Tam, 2011). These studies commonly show that increases in Gross Domestic Product per Capita (GDPC) would initially 
result in reductions in FLFP rates as economic activities shift from family farms to industrial firms. Continuing increases in GDPC would promote female educational attainments and would lessen the stigma of women joining the labour force and, hence, they would positively influence the FLFP rates.

There is a continuously renewed interest to investigate the various aspects of women's participation and contribution in the labour market for the MENA region. For instance, Chamlou (2008) studies women entrepreneurs' contribution to the social and economic development of the MENA region, and reviews the factors that promote women entrepreneurship. Chamlou et al. (2011) investigate the determinants of FLFP rates in Jordan, focusing on the role of social norms in reducing these rates. The Organization for Economic Cooperation and Development (2012) investigates women entrepreneurs' access to finance in the MENA region, describing significant gender-related obstacles. Contessi et al. (2013) examine the relationship between female ownership and entrepreneurship of manufacturing firms in the MENA region and trade openness. They also look into the effects of female labour participation on exporting activities. They find that trade openness has disproportionate implications for industries characterized by comparative advantage in terms of female ownership, entrepreneurship, and employment.

The primary objective of this paper is to examine the implications of firm-related and national economic and socio-economic factors for FLFP rates in manufacturing firms located in the MENA region. The results would assist policy-makers in understanding the demand-side factors that influence FLFP rates, and in designing strategies that enhance women's participation in the labour market. The contribution of this paper is two-fold. First, we use firm-level data rather than household characteristics data to analyze the determinants of FLFP rates in the MENA labour market. The data come from the World Bank's Enterprise Surveys database; a comprehensive and comparable source of firm-level data through many MENA countries. We also account for the role of macro-factors, such as the national economic development level and national gender inequality indicator, through the empirical analysis. 
Second, given the fractional nature of the dependent variables through our empirical analysis, we use the fractional logit model developed by Papke and Wooldridge (1996). The remainder of this paper is organized as follows. In section 2, we describe the dataset and discuss the econometric strategy. In section 3, we present and discuss the empirical results. In section 4, we provide concluding remarks.

\section{Empirical Methodology and Data}

\subsection{Empirical Methodology}

This study examines the determinants of female labour participation in manufacturing firms located in the MENA region. Female labour participation variables are represented as fractions from total employment (more details are provided in the following data sub-section). Given the fractional nature of the dependent variables, we use the seminal fractional logit model of Papke and Wooldridge (1996) to carry out the empirical investigation. The estimation model of Papke and Wooldridge (1996) is designed to take into account the bounded nature of fractional dependent variables between zero and one. These boundaries are established by definition and not by censoring (Wagner, 2001). Papke and Wooldridge (1996) model is a one-step approach where limited observations (i.e., zero female workers) and strictly positive fractions of female workers are estimated in one equation. Comparatively, the Heckman selection model is a two-step approach where the first step estimates the decision to employ female workers using the whole dataset, and the second step estimates the fraction of female workers equation. The latter estimation is carried out for firms with strictly positive fractions of female workers and it takes into account the probability of employing female workers from the first step estimation. One critical disadvantage of using the Heckman selection model is that there should be a variable in the selection equation that does not affect the outcome equation to get precise estimates (Puhani, 2000; Sartori, 2003). However, it is hard to find variables that are important for the decision 
to employ female workers but not relevant for the employment volume of female workers (and vice versa). ${ }^{3}$

Let $F_{i, c} \in[0,1]$ denote a fractional variable of female labour force participation for a given manufacturing firm " $i$ " located in a given country " $c$ " in the MENA region. The fractional logit model is represented by:

$$
E\left(F_{i, c} \mid X_{i}, Z_{c}\right)=G\left(X_{i} \alpha+Z_{c} \beta\right)=\exp \left(X_{i} \alpha+Z_{c} \beta\right) /\left[1+\exp \left(X_{i} \alpha+Z_{c} \beta\right)\right]
$$

where $X_{i}$ is a vector of firm-related variables with a corresponding vector of coefficients depicted by $\alpha, Z_{c}$ is a vector of country-related variables with a corresponding vector of coefficients depicted by $\beta$, and $0 \leq G(\cdot) \leq 1$ is the cumulative distribution function of the logistic distribution.

The marginal effects are determined using the estimated coefficients at the mean values of the explanatory variables. For a continuous explanatory variable represented by $x_{i} \in X_{i}$ with a corresponding coefficient $a \in \alpha$, we get $\quad \partial E\left(F_{i, c} \mid X_{i}, Z_{c}\right) / \partial x_{i}=a g\left(X_{i} \alpha+Z_{c} \beta\right)$, where $g\left(X_{i} \alpha+Z_{c} \beta\right)=\exp \left(X_{i} \alpha+Z_{c} \beta\right) /\left[1+\exp \left(X_{i} \alpha+Z_{c} \beta\right)\right]^{2}$. For a binary variable depicted by $w_{i} \in X_{i}$ (discrete change), we get $E\left(F_{i, c} \mid \tilde{X}_{i}, Z_{c}, w_{i}=1\right)-E\left(F_{i, c} \mid \tilde{X}_{i}, Z_{c}, w_{i}=0\right)$, where $\tilde{X}_{i}$ equals $X_{i}$ excluding $w_{i}$. The marginal effects of country variables can be similarly determined.

Equation (1) is estimated through a Quasi-Maximum Likelihood Estimator (QMLE) which maximizes the following Bernoulli log-likelihood function: ${ }^{4}$

$$
l_{i, c}(\alpha, \beta)=F_{i, c} \ln \left[G\left(X_{i} \alpha+Z_{c} \beta\right)\right]+\left(1-F_{i, c}\right) \ln \left[1-G\left(X_{i} \alpha+Z_{c} \beta\right)\right]
$$

\footnotetext{
${ }^{3}$ See Wagner (2001) for an equivalent argument in the case of firm export decision and volume, and for a discussion on the critical disadvantages of using two-step approach vis-à-vis one step approach in the case of fractional dependant variables.

${ }^{4}$ The estimated coefficients through the QMLE are consistent regardless of the distribution of $F_{i, c}$ conditional on $X_{i}$ and $Z_{c}$ (provided that Equation (1) holds), and they have satisfactory efficiency properties.
} 
where the coefficients are estimated by solving the maximization problem $\operatorname{Max}_{\alpha, \beta} \sum_{i, c} l_{i, c}(\alpha, \beta)$. The "sandwich" formula of the variance-covariance matrix indicates robustness to arbitrary heteroskedasticity and correlation between residuals (Gourieroux et al., 1984; Papke and Wooldridge, 1996).

\subsection{Data}

The dataset used through the empirical investigation is derived from the World Bank's Enterprise Surveys database. The latter represents a comprehensive source of firm-level data in emerging and developing countries, and it covers various indicators of business environment. The dataset includes 3619 manufacturing firms located in eight Arab countries in the MENA region: Algeria, Egypt, Jordan, Lebanon, Morocco, Oman, Syria, and Yemen. ${ }^{5}$ The manufacturing sectors that are covered in the dataset include: chemicals and pharmaceuticals, electronics, food, garments, leather, metals and machinery, non-metallic and plastic materials, textiles, wood and furniture, and other manufacturing.

Female labour participation is depicted by: 1) the fraction of total female full-time workers in total full-time employment and, 2) the fraction of total female non-production full-time workers in total non-production full-time workers. ${ }^{6}$ The explanatory variables related to firm characteristics include: 1) firm size measured by the number of employees; 2) firm age since establishment, 3) a binary variable that takes the value of one for an exporting firm and zero otherwise; 4) firm ownership variables depicted through the fraction of private foreign ownership in total ownership and through the fraction of government ownership in total ownership with a reference being the fraction of private domestic ownership in total ownership; 5) a binary variable representing the use of Information and

\footnotetext{
${ }^{5}$ The survey year/fiscal year are: 2002/2001 and 2007/2006 for Algeria's firms, 2007/2005 and 2008/2007 for Egypt's firms, 2006/2006 for Jordan's firms, 2009/2008 for Lebanon's firms, 2007/2005 for Morocco's firms, 2003/2002 for Oman's firms, 2003/2002 and 2009/2008 for Syria's firms, and 2010/2009 for Yemen's firms.

6 The World Bank's Enterprise Surveys database includes observations on the number of part-time workers, but it does not report representative statistics on female part-time labour participation rates.
} 
Communication Technology (ICT) that takes the value of one for firm use of own Internet website and zero otherwise; and 6) firm's labour composition variables represented through the fraction of skilled production workers in total production workers and through the fraction of non-production workers in total employment. Country variables include Gender Inequality Index (GII) sourced from the United Nations Development Programme's (UNDP's) Human Development Reports, Gross Domestic Product per Capita (GDPC) depicting national economic development level, and a national business freedom indicator. The last two variables are derived from the World Development Indicators (WDI) database of the World Bank. ${ }^{7}$

Table 2 provides descriptive statistics of the dependent and explanatory variables used through the empirical investigation. These statistics indicate that the percentage of total female full-time workers in total full-time employment has a mean of $14.8 \%$ (with a standard deviation of $22.8 \%$ ), whereas the percentage of total female non-production full-time workers in total non-production fulltime workers has a considerably lower mean of $2.9 \%$ (with a standard deviation of $6.6 \%$ ). The statistics also show that private foreign ownership has a mean of $4.3 \%$ (with a standard deviation of $18.8 \%$ ), whereas government ownership has a mean of $2.6 \%$ (with a standard deviation of $15.4 \%$ ). The surveyed manufacturing firms in our dataset have on average around 135 full-time workers (with a standard deviation of around 323 full-time workers). We find that around $36 \%$ of manufacturing firms in the sample use their own Internet websites to communicate with clients, and to source and provide information. Alternative statistics indicate that around $49 \%$ of firms use E-mail as a form of business communication. The mean of the percentage of skilled production workers in total production workers and that of the percentage of non-production workers in total employment are $61.1 \%$ (with a standard deviation of $27.0 \%$ ) and $23 \%$ (with a standard deviation of $16.7 \%$ ), respectively.

\footnotetext{
${ }^{7}$ The WDI's ease of doing business indicator is a ranking of countries according to the quality of regulatory environment in enhancing business. We inversely rank the MENA countries in our dataset, giving higher scores to more businessconducive regulatory environments. Hence, a positive coefficient on this variable would indicate a positive effect of business freedom on the dependent variable.
} 


\section{Empirical Results}

\subsection{Fraction of Female Workers in Total Employment}

The results from the empirical model explaining the fraction of female full-time workers in total fulltime employment are presented in Table 3. Column (1) shows that MENA's manufacturing firms with higher levels of private foreign ownership have higher rates of female labour participation. The corresponding marginal effect indicates that an increase in private foreign ownership by 10 percentage points induces an increase in the proportion of female workers in total employment by 1.5 percentage points. This finding can be related to other studies that report positive effects of multinational activities and foreign direct investment on female labour participation rates (e.g., Curd et al., 2007; Siegel et al., 2011). Several studies indicate that multinational firms tend to employ female workers at higher rates than domestic firms to benefit from their under-exploited skills resulting from the implications of national gender inequality (Hewlett and Rashid, 2010; Siegel et al., 2011). Furthermore, multinational enterprises, particularly those headquartered in countries with higher records of national gender equality than those prevailing in MENA countries, are arguably more resistant to the implications of social gender inequality in MENA countries. Hence, they would transfer this relative immunity into the business culture and hiring practices of their affiliated firms in MENA countries. The results also indicate that government ownership does not exhibit a statistically significant effect on female labour participation rates relative to private domestic ownership. The World Bank (2011) indicates that the public sector tends to employ more female (particularly skilled) workers than the private sector through MENA countries. For instance, the public sector generally offers more jobs that are considered to be "female-friendly" such as administration jobs. The results show that this tendency does not prevail through the MENA manufacturing firms with government ownership.

We find that MENA's manufacturing firms engaged in exporting activities have higher proportions of female workers by an average of 3.9 percentage points compared to non-exporting 
firms, ceteris paribus. This result is consistent with several empirical studies that show positive effects of exporting activities and trade openness on female labour participation rates in developing countries (e.g., International Labour Organization, 1985; Kabeer and Mahmud, 2004; Moghadam, 2005; Bussmann, 2009; Gaddis and Pieters, 2012). The positive implications of exporting activities of MENA manufacturing firms for FLFP rates complement Moghadam's (2005) observations which point out that FLFP rates tend be higher in MENA countries characterized by export-oriented manufacturing industries. Manufacturing industries in developing countries are expected to have comparative advantage in labour-intensive production. Exporting activities would further emphasize this comparative advantage, leading to increases in the proportions of female workers. Furthermore, exporting firms facing higher competition in foreign markets would be compelled to employ underexploited female labour resources. ${ }^{8}$ In this context, Kabeer and Mahmud (2004) argue that, in labourintensive exporting sectors facing important levels of market competition, the demand for women labour force is generally higher. This is because women tend to accept lower wages.

The estimated coefficient on the ICT variable is negative and statistically significant at the $10 \%$ level. The magnitude of this effect is relatively small, implying that firms using own Internet websites have lower female participation rates by 1.4 percentage points on average. There are few studies that examine the relationship between FLFP rates and ICT, focusing on the supply-side. For example, Dettling (2012) finds that the use of the Internet at home has positive implications for married women's labour supply. ${ }^{9}$ The estimated coefficient on firm size is negative but it is not statistically significant. It is commonly argued that larger firms use more complex technologies and tend to have

\footnotetext{
${ }^{8}$ Bussmann (2009) indicates that the positive effects of exporting activities on FLFP rates could enhance women's welfare through increases in personal income. The latter would help women, for example, to pursue education and to have better access to health services. However, she also argues that women could suffer from work-related stress and could continue to bear most of household-related labour beside firm-related labour. Such circumstances could negatively impact their wellbeing. The empirical results in Bussmann (2009) reveal that trade openness has positive implications for FLFP rates, but they do not offer clear evidence which indicates higher increases in women's welfare than men's welfare.

${ }^{9}$ The regressions are alternatively implemented with a binary variable that takes the value of one for firms using E-mail as a form of business communication and zero otherwise. The results are similar to those obtained through the benchmark regressions.
} 
more unpleasant working environment due to increasing labour divisions and impersonal working atmosphere (Masters, 1969; Schmidt and Zimmerman, 1991). ${ }^{10}$ This argument does not clearly prevail through the results derived from this empirical specification.

It is commonly argued in the literature that firms in developing countries tend to employ relatively more female workers for light (primarily unskilled) occupations and tasks that do not require extensive training (Çağatay and Berik. 1991; Çağatay and Özler, 1995). Accordingly, firms that are more unskilled-labour intensive in production are expected to have higher fractions of female workers. The results do not support this hypothesis since the estimated coefficient on the skilled-labour ratio is not statistically significant. The results also show that higher ratios of non-production workers negatively impact the proportion of female workers. An increase in the ratio of non-production workers by 10 percentage points reduces the proportion of female workers by 0.8 percentage points. This implies that female workers are employed at higher rates in manufacturing firms that use production labour more intensively.

The national variables exercise significant effects on female labour participation variable. A $10 \%$ increase in GDPC raises the female labour participation rate by 0.8 percentage points. ${ }^{11}$ For example, Algeria's GDPC is around four times higher than Yemen's GDPC in our dataset. The implications of economic development implies that manufacturing firms at Algeria's GDPC have, on average, higher rates of female workers than those at Yemen's GDPC by around 32.0 percentage points, ceteris paribus. ${ }^{12,13}$ The results also show that an improvement in national business freedom indicator by one point leads to an increase in female labour participation rate by a 1.0 percentage point.

\footnotetext{
${ }^{10}$ Larger firms tend to pay higher wages because they are normally expected to earn higher profits and to be more innovative and capital-intensive compared to smaller firms. They also tend to pay higher wages to compensate for disutilities in the working atmosphere (Masters, 1969; Schmidt and Zimmermann, 1991).

${ }^{11}$ The correlation coefficient between the GII and the GDPC variables is around -0.9. Consequently, the former variable is not included with the latter variable in the same regression due to multicollinearity.

12 The percentage of female workers in total employment for manufacturing firms located in Algeria has a mean of $22.9 \%$ and a standard deviation of $28.0 \%$ in our dataset. The corresponding statistics for manufacturing firms located in Yemen show a considerably lower mean of $5.4 \%$ with a standard deviation of $6.8 \%$.
} 
Column (2) of Table 3 presents the results from an empirical specification that includes sectorspecific effects. The results are generally comparable to those presented in the previous column with some differences. The marginal effect of private foreign ownership on FLFP rate remains positive and statistically significant at the $1 \%$ level, but it becomes smaller in magnitude compared to the one presented in column (1). Some sectors have higher levels of private foreign ownership than other sectors in our dataset. For example, the average private foreign ownership is $13.3 \%$ (with a standard deviation of $31.8 \%$ ) for the chemicals and pharmaceutical sector. Comparatively, the average private foreign ownership for the non-metallic and plastic materials sector is $0.8 \%$ (with a standard deviation of $7.2 \%$ ), and there are no firms with private foreign ownership in the leather sector and in the wood and furniture sector. The inclusion of sector-specific effect would partly absorb some of these variations, resulting in a lower marginal effect of private foreign ownership on FLFP rate.

The estimated coefficient on the firm size variable is negative and becomes statistically significant at the $1 \%$ level. The corresponding marginal effect is relatively small in magnitude, implying that an increase in firm size by 100 workers reduces the FLFP rate by 0.4 percentage points. Accordingly, this estimate could suggest that female workers moderately prefer to work in smaller firms rather than in larger firms with more stressful and impersonal working atmosphere. Also, the marginal effect of skilled workers ratio becomes negative and gains statistical significance at the $10 \%$ level. It implies that an increase in the skilled workers ratio by 10 percentage points reduces the FLFP rate by 0.2 percentage points. Finally, the marginal effect of non-production workers ratio remains negative and statistically significant, but it becomes moderately smaller in magnitude, in absolute term, compared to the one presented in the previous column.

\footnotetext{
${ }^{13}$ Several studies show U-shaped relationships between national FLFP rates and GDPC (e.g., Goldin, 1995; Mammen and Paxson, 2000; Tansel, 2001). At low income levels, there is a higher FLFP in family farms and businesses. An increase in income will lead to an initial decline in FLFP as economic activities shift from family farms and businesses to industrial firms. A further increase in income would promote higher female education attainment rates, and would lessen the stigma associated with women's work in firms, leading to an increase in national FLFP rates. The empirical prevalence of Ushaped relationships is typically realized using panel datasets characterized by considerable cross-country variations and evolving patterns in income per capita over time. In this study, we examine firm-level rather than national FLFP rates for a dataset covering manufacturing firms located in the MENA region through a recent time period.
} 
Column (3) of Table 3 presents the estimation results when substituting GDPC with the GII variable. ${ }^{14}$ It is commonly argued that decreases in national gender inequality can be translated into higher female labour participation rates (Mammen and Paxson, 2000). ${ }^{15}$ The results are comparable to those presented in column (1). The marginal effect of GII indicates that a decrease in this national gender inequality index by 0.1 points raises the FLFP rate in manufacturing firms by 3.2 percentage points. For example, Algeria's GII is higher than Yemen's GII by around 0.4 points. Hence, the implications of GII suggest that manufacturing firms at Algeria's GII have, on average, higher proportions of female workers than those at Yemen's GII by around 12.2 percentage points, ceteris paribus. Column (4) of Table 3 presents the results from the corresponding empirical specification that includes sector-specific effects. The marginal effects of firm-related variables are equivalent to those presented in column (3) of Table 3. The marginal effect of GII becomes smaller, in absolute terms, than the one reported in the previous column. Also, the marginal effect of the business freedom indicator becomes larger compared to the one presented in the previous column.

\subsection{Fraction of Female Non-Production Workers in Total Non-Production Workers}

Table 4 presents the corresponding empirical results explaining the fraction of female non-production full-time workers in total non-production full-time workers. The benchmark empirical results from the empirical specifications that do not include sector-specific effects are presented in columns (1) and (3). The effect of private foreign ownership is positive and statistically significant. The magnitude of this effect is considerably lower compared to the one reported in Table 3 for the overall fraction of female workers in total employment. The corresponding marginal effect indicates that an increase in private foreign ownership by 10 percentage points induces an increase in the proportion of female non-

\footnotetext{
${ }^{14}$ Positive relationships are commonly documented in the literature between economic development and national gender equality (e.g., Weiss et al., 1976; Clark et al., 1991; Abu Ghaida and Klasen, 2002; Klasen and Lamanna, 2009; Cuberes and Teignier-Baqué, 2011).

${ }^{15}$ Increases in female labour participation rates per se may not be necessarily a sign of a decline in gender inequality (Standing, 1999; Klasen and Pieters, 2012).
} 
production workers by only 0.2 percentage points. Hence, the results suggest that multinational manufacturing firms in the MENA region have a moderately higher propensity to employ female labour in non-production positions than domestic manufacturing firms. Also, the review of the results in Table 3 and Table 4 indicates that these multinational manufacturing firms have a higher propensity to employ female labour in production positions than in non-production occupations. The estimated coefficient on the government ownership variable is not statistically significant. Hence, the results suggest that the higher tendency of the public sector to employ female workers (The World Bank, 2011) is not extended to cover non-production positions through the MENA manufacturing firms with government ownership.

The results indicate that the effect of exporting activities is not statistically significant. The review of the results in Table 3 and Table 4 suggests that exporting activities of manufacturing firms generate a higher propensity to employ female labour in production positions, but not in nonproduction positions. This outcome could be related to Kabeer and Mahmud's (2004) argument, being indicative of a higher tendency of production female workers to accept lower wages than nonproduction female workers. The estimated coefficient on the ICT variable is positive and statistically significant. It indicates that firms using their own Internet websites have higher rates of female nonproduction workers by around six percentage points on average. This effect suggests that the Internet facilitates the employment of under-utilized non-production female labour. Finally, the results show that manufacturing firms with higher ratios of non-production workers have higher rates of female non-production labour participation. Specifically, an increase in the ratio of non-production workers by 10 percentage points raises the proportion of female non-production workers in total non-production employment by 0.7 percentage points, ceteris paribus.

National variables have considerably lower effects on the fraction of female non-production workers in total non-production employment compared to their effects on the overall fraction of female 
workers in total employment as reported in Table 3. A $10 \%$ increase in GDPC raises the proportion of female non-production workers by 0.3 percentage points whereas a decrease in GII by 0.1 points raises this proportion by 1.0 percentage point. These results are reminiscent of some initial findings that report significant enhancing effects of economic development on female participation rates in production labour, but small effects on female participation rates in non-production labour (e.g., Weiss et al., 1976). Business freedom indicator does not exhibit a statistically significant effect on the fraction of female non-production workers. Finally, the results from the corresponding empirical specifications that include sector-specific effects, presented in columns (2) and (4) of Table 4, are found to be comparable to the benchmark results.

\section{Conclusion}

MENA countries have realized significant advances through several aspects of women's well being over the last few decades. However, women's labour force participation rate in the MENA region remains one of the lowest in the world. This paper examines the implications of firm-related and national economic and socio-economic factors for FLFP rates in the manufacturing firms located in the MENA region. The empirical investigation uses data derived from the World Bank's Enterprise Surveys database and implements the seminal fractional logit model of Papke and Wooldridge (1996) to carry out the estimation.

The main results indicate that private foreign ownership and exporting activities promote overall FLFP rates. The relative labour composition of firms in terms of non-production workers is found to have a negative effect on overall FLFP rates. The results underscore positive implications of national economic development and business freedom for overall FLFP rates. Also, the results show that higher levels of gender inequality exert negative effects on overall FLFP rates. The empirical investigation is then implemented for women's participation in non-production labour force. The results reveal a positive effect of private foreign ownership on female non-production labour force 
participation rates. However, this effect is found to be smaller in magnitude compared to the corresponding effect on overall FLFP rates. Also, exporting activities do not exert a statistically significant effect on women's non-production labour force participation rates. These findings suggest that the implications of private foreign ownership and exporting activities are primarily prevailing for women's production labour force participation rates. The results show a positive effect of national economic development factors on women's non-production labour force participation rates. This effect is also found to be smaller in magnitude compared to the one exercised on overall FLFP rates. These findings suggest that the implications of national economic development levels are more important for women's production labour participation rates than for women's non-production labour participation rates through the MENA's manufacturing sector.

This paper provides policy-makers and analysts with directions to design strategies aiming to enhance women's labour participation rates through the manufacturing sector in the MENA region. ${ }^{16}$ The positive implications of private foreign ownership and exporting activities for FLFP rates underline the benefits of policies that promote inward foreign direct investment and facilitate exports. Nevertheless, the differing implications of private foreign ownership and exporting activities for women's participation rates in production and non-production labour force should be further investigated. Finally, the results depicting the positive effects of national gender equality on FLFP rates suggest that MENA governments should continue to adopt policies that promote women's wellbeing, social status, and education to realize higher women's participation rates in MENA's labour markets.

\footnotetext{
${ }^{16}$ Fogli and Veldkamp (2011) indicate that policies that lead to initial increases in FLFP rates can enhance the transmission of information on the effects of maternal employment on children. The accumulation of information would decrease uncertainty regarding maternal employment and would accelerate women's participation in the labour market.
} 


\section{References}

Abe, Y. 2011. "Regional Variations in Labor Force Behavior of Women in Japan." Working Paper No. 2010-12, Center for Economic Institutions (CEI), Institute of Economic Research, Hitotsubashi University, Tokyo, Japan.

Abu Ghaida, D., and S. Klasen. 2002. The Costs of Missing the Millennium Development Goal on Gender Equity. The World Bank, Washington, DC.

Buchanan, J., L. Scott, S. Yu, H. Schutz, and M. Jakubauskas. 2010. "Skills Demand and Utilisation: An International Review of Approaches to Measurement and Policy Development." Local Economic and Employment Development (LEED) Working Paper No. 2010/04, Organization for Economic Cooperation and Development (OECD) Publishing, Paris, France.

Bussmann, M. 2009. "The Effect of Trade Openness on Women's Welfare and Work Life." World Development, 37(6): 1027-1038.

Çağatay, N., and G. Berik. 1991. "Transition to Export-led Growth in Turkey: Is There a Feminisation of Employment?" Capital and Class, 15(1): 153-177.

Çağatay, N., and S. Özler. 1995. "Feminization of the Labour Force: The Effects of Long-Term Development and Structural Adjustment." World Development, 23(11): 1883-1894.

Chamlou, N. 2008. The Environment for Women Entrepreneurship in the Middle East and North Africa. The World Bank, Washington, DC.

Chamlou, N., S. Muzi, and H. Ahmed. 2011. "Understanding the Determinants of Female Labor Force Participation in the Middle East and North Africa Region: The Role of Education and Social Norms in Amman.” Working Paper No. 31, AlmaLaurea Inter-University Consortium, Bologna, Italy.

Clark, R., T.W. Ramsbey, and E.S. Adler. 1991. "Culture, Gender, and Labor Force Participation: A Cross-National Study." Gender and Society, 5(1): 47-66.

Contessi, S., F. de Nicola, and L. Li. 2013. "International Trade, Female Labor, and Entrepreneurship in MENA Countries." Federal Reserve Bank of St. Louis Review, 94(3): 197-220.

Cuberes, D., and M. Teignier-Baqué. 2011. "Gender Inequality and Economic Growth.” Background Paper for World Development Report 2012: Gender Equality and Development. The World Bank, Washington, DC.

Curd, A., A. Julian, A. Sabow, and L. Seligman. 2007. "The Impact of Foreign Direct Investment on Chinese Women." In A. Dayal-Gulati, M. Finn, and D. Diermeier (Eds.), Global Corporate Citizenship. Northwestern University Press, Evanston, IL.

Dettling, L.J. 2012. "Opting Back In: Home Internet Use and Female Labor Supply.” Working Paper, Department of Economics, University of Maryland, College Park, MD. 
Fogli, A., and L. Veldkamp. 2011. "Nature or Nurture? Learning and the Geography of Female Labor Force Participation.” Econometrica, 79(4): 1103-1138.

Gaddis, I., and J. Pieters. 2012. "Trade Liberalization and Female Labor Force Participation. Evidence from Brazil.” IZA Discussion Paper No. 6809, Institute for the Study of Labor, Bonn, Germany.

Goldin, C. 1995. "The U-Shaped Female Labor Force Function in Economic Development and Economic History." In T.P. Schultz (Ed.), Investment in Women's Human Capital and Economic Development. University of Chicago Press, Chicago, IL.

Gourieroux, C., A. Monfort, and A. Trognon. 1984. "Pseudo-Maximum Likelihood Methods: Theory." Econometrica, 52(3): 681-700.

Greenwood, J., A. Seshadri, and M. Yorukoglu. 2005. "Engines of Liberation." Review of Economic Studies, 72(1): 109-133.

Gronau, R. 1973. "The Effect of Children on the Housewife's Value of Time." Journal of Political Economy, 81(2): S168-S199.

Heckman, J.J. 1974. "Shadow Prices, Market Wages and Labor Supply.” Econometrica, 42(4): 679694.

Hewlett, S.A., and R. Rashid. 2010. "The Battle for Female Talent in Emerging Markets." Harvard Business Review, 88(5): 101-106.

International Labour Organization (ILO). 1985. Women Workers in Multinational Enterprises in Developing Countries. International Labour Organization, Geneva, Switzerland.

International Labour Organization (ILO). 2012. Global Employment Trends 2012: Preventing a Deeper Jobs Crisis. International Labour Organization, Geneva, Switzerland.

Kabeer, N., and S. Mahmud. 2004. "Globalization, Gender and Poverty: Bangladeshi Women Workers in Export and Local Markets.” Journal of International Development, 16(1): 93-109.

Karaoglan, D., and C. Okten. 2012. "Labor Force Participation of Married Women in Turkey: Is There an Added or a Discouraged Worker Effect?" IZA Discussion Paper No. 6616, Institute for the Study of Labor, Bonn, Germany.

Killingworth, M.R., and J.J. Heckman. 1986. "Female Labor Supply: A Survey.” In O. Ashenfelter and R. Laynard (Eds.), Handbook of Labor Economics. Elsevier Science Publishers, New York, NY.

Klasen, S., and F. Lamanna. 2009. "The Impact of Gender Inequality in Education and Employment on Economic Growth: New Evidence for a Panel of Countries." Feminist Economics, 15(3): 91-132.

Klasen, S., and J. Pieters. 2012. "Push or Pull? Drivers of Female Labor Force Participation during India's Economic Boom.” IZA Discussion Paper No. 6395, Institute for the Study of Labor, Bonn, Germany. 
Kohara, M. 2010. “The Response of Japanese Wives' Labor Supply to Husbands' Job Loss.” Journal of Population Economics, 23(4): 1133-1149.

Lee, B.S., S. Jang, and J. Sarkar. 2008. "Women Labor Force Participation and Marriage: The Case of Korea." Journal of Asian Economics, 19(2): 138-154.

Mammen, K., and C. Paxson. 2000. "Women's Work and Economic Development." Journal of Economic Perspectives, 14(4): 141-164.

Masters, S.H. 1969. “An Interindustry Analysis of Wages and Plant Size.” Review of Economics and Statistics, 51(3): 341-345.

Mincer, J. 1962. "Labor Force Participation of Married Women: A Study of Labor Supply.” In H.G. Lewis (Ed.), Aspects of Labor Economics. Princeton University Press, Princeton, NJ.

Moghadam, V. 2005. Globalizing Women: Transnational Feminist Networks. The Johns Hopkins University Press, Baltimore, MD.

Morrison, A.R., S. Sabarwal, and M. Sjöblom. 2008. “The State of World Progress, 1990-2007.” In M. Buvinić, A.R. Morrison, A.W. Ofosu-Amaah, and M. Sjöblom (Eds.), Equality for Women: Where Do We Stand on the Millennium Development Goals 3?. The International Bank for Reconstruction and Development/The World Bank, Washington, DC.

Papke, L.E., and J.M. Wooldridge. 1996. "Econometric Methods for Fractional Response Variables with an Application to 401(k) Plan Participation Rates." Journal of Applied Econometrics, 11(4): 619632.

Pissarides, C., P. Garibaldi, C. Olivetti, B. Petrongolo, and E. Wasmer. 2005. "Women in the Labour Force: How Well is Europe Doing?” In T. Boeri, D. Del Boca, and C. Pissarides (Eds.), Women at Work: An Economic Perspective. Oxford University Press, London, UK.

Prieto-Rodríguez, J., and C. Rodríguez-Guitiérrez. 2003. "Participation of Married Women in the European Labor Markets and the Added Worker Effect." Journal of Socio-Economics, 32(4): 429-446.

Puhani, P. 2000. "The Heckman Correction for Sample Selection and its Critique." Journal of Economic Surveys, 14(1): 53-68.

Rauch, J.E., and S. Kostyshak. 2009. "The Three Arab Worlds.” Journal of Economic Perspectives, 23(2): 165-188.

Sartori, A. 2003. "An Estimator for Some Binary-Outcome Selection Models without Exclusion Restrictions.” Political Analysis, 11(2):111-138.

Schmidt, C.M., and K.F. Zimmermann. 1991. "Work Characteristics, Firm Size and Wages." Review of Economics and Statistics, 73(4): 705-710. 
Siegel, J., L. Pyun, and B.Y. Cheon. 2011. "Multinational Firms, Labor Market Discrimination, and the Capture of Competitive Advantage by Exploiting the Social Divide." Working Paper No. 11-011, Harvard Business School, Boston, MA.

Standing, G. 1999. "Global Feminization Through Flexible Labor: A Theme Revisited." World Development, 27(3): 583-602.

Tam, H. 2011. "U-Shaped Female Labor Participation with Economic Development: Some Panel Data Evidence.” Economic Letters, 110(2): 140-142.

Tansel, A. 2001. "Economic Development and Female Labor Force Participation in Turkey: TimeSeries Evidence and Cross-Province Estimates." Economic Research Forum Working No. 01/05, Department of Economics, Middle East Technical University, Ankara, Turkey.

The Organization for Economic Cooperation and Development (OECD). 2012. "MENA Women Entrepreneurs' Access to Credit and Financial Services." In OECD, Women in Business: Policies to Support Women's Entrepreneurship Development in the MENA Region. OECD Publishing, Paris, France.

The World Bank. 2011. Capabilities, Opportunities and Participation: Gender Equality and Development in the Middle East and North Africa Region. The World Bank, Washington, DC.

Wagner, J. 2001. "A Note on the Firm Size - Export Relationship.” Small Business Economics, 17(4): 229-237.

Weiss, J.A., F.O. Ramirez, and T. Tracy. 1976. "Female Participation in the Occupational System: A Comparative Institutional Analysis." Social Problems, 23(5): 525-534. 
Table 1. Labour market indicators by geo-economic region

\begin{tabular}{|c|c|c|c|c|c|}
\hline & \multirow[t]{2}{*}{$\begin{array}{l}\text { Annual real GDP } \\
\text { growth rate }(\%)\end{array}$} & \multicolumn{2}{|c|}{$\begin{array}{l}\text { Unemployment rate } \\
(\%)\end{array}$} & \multirow{2}{*}{$\begin{array}{c}\begin{array}{c}\text { Employment- } \\
\text { to-population } \\
\text { ratio }(\%)\end{array} \\
\text { Female }\end{array}$} & \multirow{2}{*}{$\begin{array}{c}\text { Annual } \\
\text { employment } \\
\text { growth rate }(\%)\end{array}$} \\
\hline & & Youth & Female & & \\
\hline \multicolumn{6}{|l|}{ Year: 2006} \\
\hline ME & 6.0 & 25.5 & 19.3 & 15.1 & 4.6 \\
\hline NA & 5.9 & 25.2 & 18.0 & 18.6 & 3.4 \\
\hline World & 25.3 & 12.4 & 6.2 & 488.9 & 1.8 \\
\hline $\mathrm{DE}$ and $\mathrm{EU}$ & 3.0 & 13.3 & 6.7 & 49.0 & 0.9 \\
\hline EA & 10.9 & 8.3 & 3.3 & 65.6 & 1.2 \\
\hline SEAP & 6.2 & 17.0 & 6.6 & 54.4 & 1.7 \\
\hline SA & 8.9 & 9.3 & 4.4 & 34.7 & 2.5 \\
\hline LAC & 5.6 & 15.3 & 9.8 & 46.5 & 2.5 \\
\hline SSA & 6.5 & 12.8 & 8.9 & 58.5 & 3.1 \\
\hline \multicolumn{6}{|l|}{ Year: 2009} \\
\hline ME & 2.2 & 25.2 & 18.7 & 14.5 & 4.0 \\
\hline NA & 3.5 & 23.6 & 16.5 & 19.8 & 2.2 \\
\hline World & -0.7 & 12.8 & 6.4 & $\overline{~ 48.1}$ & 0.5 \\
\hline $\mathrm{DE}$ and $\mathrm{EU}$ & -3.9 & 17.3 & 7.9 & 48.9 & -2.2 \\
\hline EA & 7.1 & 9.0 & 3.6 & 64.6 & 0.7 \\
\hline SEAP & 1.6 & 13.9 & 5.2 & 55.5 & 1.7 \\
\hline SA & 6.2 & 9.1 & 4.4 & 31.4 & 0.6 \\
\hline LAC & -1.7 & 15.7 & 9.6 & 47.5 & 0.7 \\
\hline SSA & 2.8 & 12.9 & 8.7 & 58.8 & 2.7 \\
\hline \multicolumn{6}{|l|}{ Year: 2010} \\
\hline ME & 4.4 & 25.4 & 18.5 & 14.8 & 3.8 \\
\hline NA & 4.4 & 23.0 & 16.4 & 20.0 & 2.2 \\
\hline World & 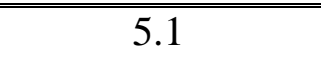 & 12.8 & 6.5 & 47.8 & 1.3 \\
\hline $\mathrm{DE}$ and EU & 2.6 & 18.1 & 8.4 & 48.6 & -0.2 \\
\hline EA & 9.8 & 8.8 & 3.5 & 64.6 & 0.9 \\
\hline SEAP & 7.5 & 13.6 & 5.2 & 55.5 & 2.2 \\
\hline SA & 9.2 & 10.2 & 5.0 & 30.1 & 0.7 \\
\hline LAC & 6.1 & 14.6 & 9.1 & 48.4 & 2.8 \\
\hline SSA & 5.4 & 12.8 & 8.7 & 58.7 & 2.7 \\
\hline
\end{tabular}

Source: International Labour Organization (2012).

Notes: ME=Middle East; NA=North Africa; DE=Developed Economies; EU=European Union; $\mathrm{EA}=$ East Asia; SEAP=South-East Asia and the Pacific; SA=South Asia; LAC=Latin America and the Caribbean; SSA=Sub-Saharan Africa; GDP=Gross Domestic Product. The annual employment growth rates for 2006 are reported as averages over 2001-2006. 
Table 2. Descriptive statistics

\begin{tabular}{l|c|c}
\hline \hline & Mean & Standard deviation \\
\hline \hline Dependent variables & & \\
Female full-time workers (fraction in total full-time & 0.148 & 0.228 \\
employment) & & \\
Female non-production full-time workers (fraction in & 0.029 & 0.066 \\
total non-production full-time workers) & & \\
& & \\
Explanatory variables & & \\
Foreign ownership (fraction in total ownership) & 0.043 & 0.188 \\
Government ownership (fraction in total ownership) & 0.026 & 0.154 \\
Exporting firm (binary variable) & 0.308 & 0.461 \\
Firm size (total employment) & 134.811 & 322.594 \\
Firm age (years) & 21.038 & 16.436 \\
Skilled/Total production workers & 0.611 & 0.270 \\
Non-production/Total employment & 0.232 & 0.167 \\
Firm use of ICT, Internet website (binary variable) & 0.359 & 0.479 \\
Firm use of ICT, E-mail (binary variable) & 0.489 & 0.500 \\
GDPC (current USD) & $2,198.275$ & 932.863 \\
Gender inequality index (national indicator) & 0.554 & 0.073 \\
Business freedom (national indicator) & 5.337 & 1.643 \\
\hline \hline Number of observations & & \\
\hline \hline
\end{tabular}


Table 3. Fraction of female full-time workers (fractional logit model)

\begin{tabular}{|c|c|c|c|c|c|c|c|c|}
\hline & \multicolumn{2}{|c|}{ (1) } & \multicolumn{2}{|c|}{ (2) } & \multicolumn{2}{|c|}{ (3) } & \multicolumn{2}{|c|}{$(4)$} \\
\hline & Coeff. & $\begin{array}{c}\text { Marginal } \\
\text { effect }\end{array}$ & Coeff. & $\begin{array}{c}\text { Marginal } \\
\text { effect }\end{array}$ & Coeff. & $\begin{array}{c}\text { Marginal } \\
\text { effect }\end{array}$ & Coeff. & $\begin{array}{c}\text { Marginal } \\
\text { effect }\end{array}$ \\
\hline Foreign ownership & $\begin{array}{c}1.224 * * * \\
(0.121)\end{array}$ & $\begin{array}{c}0.148 * * * \\
(0.015)\end{array}$ & $\begin{array}{c}0.772^{* * *} \\
(0.124)\end{array}$ & $\begin{array}{c}0.082^{* * *} \\
(0.013)\end{array}$ & $\begin{array}{c}1.273 * * * \\
(0.122)\end{array}$ & $\begin{array}{c}0.155^{* * *} * \\
(0.015)\end{array}$ & $\begin{array}{c}0.895 * * * \\
(0.124)\end{array}$ & $\begin{array}{c}0.097 * * * \\
(0.014)\end{array}$ \\
\hline Government ownership & $\begin{array}{l}-0.248 \\
(0.210)\end{array}$ & $\begin{array}{l}-0.030 \\
(0.025)\end{array}$ & $\begin{array}{c}0.006 \\
(0.200)\end{array}$ & $\begin{array}{c}0.001 \\
(0.021)\end{array}$ & $\begin{array}{l}-0.291 \\
(0.211)\end{array}$ & $\begin{array}{l}-0.035 \\
(0.026)\end{array}$ & $\begin{array}{l}-0.070 \\
(0.201)\end{array}$ & $\begin{array}{l}-0.008 \\
(0.022)\end{array}$ \\
\hline Exporting firm & $\begin{array}{c}0.310 * * * \\
(0.074)\end{array}$ & $\begin{array}{c}0.039 * * * \\
(0.010)\end{array}$ & $\begin{array}{c}0.330 * * * \\
(0.073)\end{array}$ & $\begin{array}{c}0.037 * * * \\
(0.009)\end{array}$ & $\begin{array}{c}0.265^{* * *} * \\
(0.074)\end{array}$ & $\begin{array}{c}0.033 * * * \\
(0.010)\end{array}$ & $\begin{array}{c}0.244 * * * \\
(0.074)\end{array}$ & $\begin{array}{c}0.027 * * * \\
(0.009)\end{array}$ \\
\hline Firm size & $\begin{array}{l}-0.011 \\
(0.008)\end{array}$ & $\begin{array}{l}-0.001 \\
(0.001)\end{array}$ & $\begin{array}{c}-0.038 * * * \\
(0.009)\end{array}$ & $\begin{array}{c}-0.004 * * * \\
(0.001)\end{array}$ & $\begin{array}{l}-0.011 \\
(0.008)\end{array}$ & $\begin{array}{l}-0.001 \\
(0.001)\end{array}$ & $\begin{array}{c}-0.036 * * * \\
(0.009)\end{array}$ & $\begin{array}{c}-0.004 * * * \\
(0.001)\end{array}$ \\
\hline Firm age & $\begin{array}{l}-0.002 \\
(0.002)\end{array}$ & $\begin{array}{c}0.000 \\
(0.000)\end{array}$ & $\begin{array}{c}0.002 \\
(0.002)\end{array}$ & $\begin{array}{c}0.000 \\
(0.000)\end{array}$ & $\begin{array}{l}-0.002 \\
(0.002)\end{array}$ & $\begin{array}{c}0.000 \\
(0.000)\end{array}$ & $\begin{array}{c}0.002 \\
(0.002)\end{array}$ & $\begin{array}{c}0.000 \\
(0.000)\end{array}$ \\
\hline Skilled workers ratio & $\begin{array}{c}0.060 \\
(0.115)\end{array}$ & $\begin{array}{c}0.007 \\
(0.014)\end{array}$ & $\begin{array}{c}-0.195^{*} \\
(0.113)\end{array}$ & $\begin{array}{l}-0.021^{*} \\
(0.012)\end{array}$ & $\begin{array}{c}0.056 \\
(0.115)\end{array}$ & $\begin{array}{c}0.007 \\
(0.014)\end{array}$ & $\begin{array}{l}-0.187 \\
(0.115)\end{array}$ & $\begin{array}{l}-0.020 \\
(0.012)\end{array}$ \\
\hline Non-production workers ratio & $\begin{array}{c}-0.662 * * * \\
(0.186)\end{array}$ & $\begin{array}{c}-0.080 * * * \\
(0.023)\end{array}$ & $\begin{array}{c}-0.429 * * \\
(0.185)\end{array}$ & $\begin{array}{c}-0.046 * * \\
(0.020)\end{array}$ & $\begin{array}{c}-0.694 * * * \\
(0.185)\end{array}$ & $\begin{array}{c}-0.085^{* * * *} \\
(0.023)\end{array}$ & $\begin{array}{c}-0.447 * * \\
(0.185)\end{array}$ & $\begin{array}{c}-0.048 * * \\
(0.020)\end{array}$ \\
\hline Firm use of ICT & $\begin{array}{c}-0.119 * \\
(0.071)\end{array}$ & $\begin{array}{c}-0.014^{*} \\
(0.008)\end{array}$ & $\begin{array}{c}0.013 \\
(0.069)\end{array}$ & $\begin{array}{c}0.001 \\
(0.007)\end{array}$ & $\begin{array}{l}-0.095 \\
(0.071)\end{array}$ & $\begin{array}{l}-0.012 \\
(0.009)\end{array}$ & $\begin{array}{c}0.049 \\
(0.070)\end{array}$ & $\begin{array}{c}0.005 \\
(0.008)\end{array}$ \\
\hline $\operatorname{Ln}(\mathrm{GDPC})$ & $\begin{array}{c}0.678 * * * \\
(0.084)\end{array}$ & $\begin{array}{c}0.082 * * * \\
(0.010)\end{array}$ & $\begin{array}{c}0.850 * * * \\
(0.083)\end{array}$ & $\begin{array}{c}0.090 * * * \\
(0.009)\end{array}$ & & & & \\
\hline Gender inequality index (GII) & & & & & $\begin{array}{c}-2.585 * * * \\
(0.543)\end{array}$ & $\begin{array}{c}-0.315 * * * \\
(0.066)\end{array}$ & $\begin{array}{c}-1.495 * * * \\
(0.567)\end{array}$ & $\begin{array}{c}-0.162 * * * \\
(0.061)\end{array}$ \\
\hline Business freedom & $\begin{array}{c}0.080 * * * \\
(0.018)\end{array}$ & $\begin{array}{c}0.010 * * * \\
(0.002)\end{array}$ & $\begin{array}{c}0.116^{* * * *} \\
(0.018)\end{array}$ & $\begin{array}{c}0.012 * * * \\
(0.002)\end{array}$ & $\begin{array}{c}0.049 * * \\
(0.023) \\
\end{array}$ & $\begin{array}{c}0.006^{* *} \\
(0.003)\end{array}$ & $\begin{array}{c}0.122 * * * \\
(0.024)\end{array}$ & $\begin{array}{c}0.013 * * * \\
(0.003)\end{array}$ \\
\hline Sector-specific effects & \multicolumn{2}{|c|}{ No } & \multicolumn{2}{|c|}{ Yes } & \multicolumn{2}{|c|}{ No } & \multicolumn{2}{|c|}{ Yes } \\
\hline Number of observations & \multicolumn{2}{|c|}{3619} & \multicolumn{2}{|c|}{3619} & \multicolumn{2}{|c|}{3619} & \multicolumn{2}{|c|}{3619} \\
\hline
\end{tabular}

Notes: Statistical significance: $*=10 \% ; * *=5 \% ; * * *=1 \%$. Robust standard errors are in parentheses. 
Table 4. Fraction of female full-time non-production workers (fractional logit model)

\begin{tabular}{|c|c|c|c|c|c|c|c|c|}
\hline & \multicolumn{2}{|c|}{ (1) } & \multicolumn{2}{|c|}{ (2) } & \multicolumn{2}{|c|}{ (3) } & \multicolumn{2}{|c|}{ (4) } \\
\hline & Coeff. & $\begin{array}{c}\text { Marginal } \\
\text { effect }\end{array}$ & Coeff. & $\begin{array}{c}\text { Marginal } \\
\text { effect }\end{array}$ & Coeff. & $\begin{array}{c}\text { Marginal } \\
\text { effect }\end{array}$ & Coeff. & $\begin{array}{c}\text { Marginal } \\
\text { effect }\end{array}$ \\
\hline Foreign ownership & $\begin{array}{c}0.698 * * * \\
(0.127)\end{array}$ & $\begin{array}{c}0.016^{* * *} * \\
(0.003)\end{array}$ & $\begin{array}{c}0.532 * * * \\
(0.119)\end{array}$ & $\begin{array}{c}0.011 * * * \\
(0.002)\end{array}$ & $\begin{array}{c}0.774 * * * \\
(0.126)\end{array}$ & $\begin{array}{c}0.018 * * * \\
(0.003)\end{array}$ & $\begin{array}{c}0.657 * * * \\
(0.117)\end{array}$ & $\begin{array}{c}0.014 * * * \\
(0.003)\end{array}$ \\
\hline Government ownership & $\begin{array}{c}0.015 \\
(0.221)\end{array}$ & $\begin{array}{c}0.000 \\
(0.005)\end{array}$ & $\begin{array}{c}0.074 \\
(0.208)\end{array}$ & $\begin{array}{c}0.001 \\
(0.004)\end{array}$ & $\begin{array}{l}-0.092 \\
(0.223)\end{array}$ & $\begin{array}{l}-0.002 \\
(0.005)\end{array}$ & $\begin{array}{l}-0.040 \\
(0.216)\end{array}$ & $\begin{array}{l}-0.001 \\
(0.005)\end{array}$ \\
\hline Exporting firm & $\begin{array}{c}0.015 \\
(0.104)\end{array}$ & $\begin{array}{c}0.000 \\
(0.002)\end{array}$ & $\begin{array}{c}0.064 \\
(0.089)\end{array}$ & $\begin{array}{c}0.001 \\
(0.002)\end{array}$ & $\begin{array}{c}0.061 \\
(0.101)\end{array}$ & $\begin{array}{c}0.001 \\
(0.002)\end{array}$ & $\begin{array}{c}-0.073 \\
(0.087)\end{array}$ & $\begin{array}{l}-0.002 \\
(0.002)\end{array}$ \\
\hline Firm size & $\begin{array}{l}0.015^{*} \\
(0.008)\end{array}$ & $\begin{array}{l}0.0003^{*} \\
(0.0002)\end{array}$ & $\begin{array}{c}0.002 \\
(0.009)\end{array}$ & $\begin{array}{c}0.000 \\
(0.000)\end{array}$ & $\begin{array}{c}0.010 \\
(0.009)\end{array}$ & $\begin{array}{c}0.000 \\
(0.000)\end{array}$ & $\begin{array}{c}0.002 \\
(0.009)\end{array}$ & $\begin{array}{c}0.000 \\
(0.000)\end{array}$ \\
\hline Firm age & $\begin{array}{c}0.000 \\
(0.002)\end{array}$ & $\begin{array}{c}0.000 \\
(0.000)\end{array}$ & $\begin{array}{c}0.003 \\
(0.002)\end{array}$ & $\begin{array}{c}0.000 \\
(0.000)\end{array}$ & $\begin{array}{c}0.001 \\
(0.002)\end{array}$ & $\begin{array}{c}0.000 \\
(0.000)\end{array}$ & $\begin{array}{c}0.002 \\
(0.002)\end{array}$ & $\begin{array}{c}0.000 \\
(0.000)\end{array}$ \\
\hline Skilled workers ratio & $\begin{array}{c}0.036 \\
(0.144)\end{array}$ & $\begin{array}{c}0.001 \\
(0.003)\end{array}$ & $\begin{array}{l}-0.025 \\
(0.123)\end{array}$ & $\begin{array}{l}-0.001 \\
(0.003)\end{array}$ & $\begin{array}{c}0.015 \\
(0.144)\end{array}$ & $\begin{array}{c}0.000 \\
(0.003)\end{array}$ & $\begin{array}{l}-0.011 \\
(0.124)\end{array}$ & $\begin{array}{c}0.000 \\
(0.003)\end{array}$ \\
\hline Non-production workers ratio & $\begin{array}{c}3.032 * * * \\
(0.198)\end{array}$ & $\begin{array}{c}0.068 * * * \\
(0.005)\end{array}$ & $\begin{array}{c}3.222 * * * \\
(0.181)\end{array}$ & $\begin{array}{c}0.065 * * * \\
(0.004)\end{array}$ & $\begin{array}{c}2.903 * * * \\
(0.195)\end{array}$ & $\begin{array}{c}0.069 * * * \\
(0.005)\end{array}$ & $\begin{array}{c}3.060 * * * \\
(0.179)\end{array}$ & $\begin{array}{c}0.067 * * * \\
(0.004)\end{array}$ \\
\hline Firm use of ICT & $\begin{array}{c}0.202 * * \\
(0.088)\end{array}$ & $\begin{array}{c}0.005 * * \\
(0.002)\end{array}$ & $\begin{array}{c}0.201 * * \\
(0.080)\end{array}$ & $\begin{array}{c}0.004 * * \\
(0.002)\end{array}$ & $\begin{array}{c}0.261 * * * \\
(0.088)\end{array}$ & $\begin{array}{c}0.006^{* * * *} \\
(0.002)\end{array}$ & $\begin{array}{c}0.254 * * * \\
(0.081)\end{array}$ & $\begin{array}{c}0.006^{* * * *} \\
(0.002)\end{array}$ \\
\hline $\operatorname{Ln}(\mathrm{GDPC})$ & $\begin{array}{c}1.242 * * * \\
(0.137)\end{array}$ & $\begin{array}{c}0.028 * * * \\
(0.003)\end{array}$ & $\begin{array}{c}1.423 * * * \\
(0.097)\end{array}$ & $\begin{array}{c}0.029 * * * \\
(0.002)\end{array}$ & & & & \\
\hline Gender inequality index (GII) & & & & & $\begin{array}{c}-4.200 * * * \\
(0.756)\end{array}$ & $\begin{array}{c}-0.100 * * * \\
(0.019)\end{array}$ & $\begin{array}{c}-4.637 * * * \\
(0.591)\end{array}$ & $\begin{array}{c}-0.101 * * * \\
(0.013)\end{array}$ \\
\hline Business freedom & $\begin{array}{c}0.025 \\
(0.022) \\
\end{array}$ & $\begin{array}{c}0.001 \\
(0.000)\end{array}$ & $\begin{array}{c}0.048 * * \\
(0.022)\end{array}$ & $\begin{array}{c}0.001 * * \\
(0.000)\end{array}$ & $\begin{array}{c}-0.036 \\
(0.028)\end{array}$ & $\begin{array}{l}-0.001 \\
(0.001)\end{array}$ & $\begin{array}{c}-0.011 \\
(0.024)\end{array}$ & $\begin{array}{c}0.000 \\
(0.001)\end{array}$ \\
\hline Sector-specific effects & \multicolumn{2}{|c|}{ No } & \multicolumn{2}{|c|}{ Yes } & \multicolumn{2}{|c|}{ No } & \multicolumn{2}{|c|}{ Yes } \\
\hline Number of observations & \multicolumn{2}{|c|}{3619} & \multicolumn{2}{|c|}{3619} & \multicolumn{2}{|c|}{3619} & \multicolumn{2}{|c|}{3619} \\
\hline
\end{tabular}

Notes: Statistical significance: $*=10 \% ; * *=5 \% ; * * *=1 \%$. Robust standard errors are in parentheses. 
